\title{
Epizootic cutaneous papillomatosis in roach Rutilus rutilus: sex and size dependence, seasonal occurrence and between-population differences
}

\author{
Raine Kortet* ${ }^{*}$ Anssi Vainikka, Jouni Taskinen \\ Department of Biological and Environmental Science, University of Jyväskylä, PO Box 35 (YAC341), 40351 Jyväskylä, Finland
}

\begin{abstract}
Epidemiology of epidermal papillomatosis in roach Rutilus rutilus was studied in 11 roach populations in Finland in 1999 and 2000 during the spawning period. In addition, the seasonal pattern of the disease was described in 1 population. Papilloma tumours were observed on the skin and fins of roach in 8 populations out of 11. Prevalence of papillomatosis varied from 0 to $62 \%$, being higher in populations subject to industrial or sewage effluents. Males and large fish had higher prevalence of papilloma tumours. The disease outbreak peaked during the spawning period and signs of recovered skin on fish were observed later during the year. The gender dependence in the disease prevalence found in the study may indicate differences in stress and immunocompetence between roach males and females during the spawning period.
\end{abstract}

KEY WORDS: Spawning papillomatosis · Roach · Tumours · Seasonality · Gender dependence · Pollution Resale or republication not permitted without written consent of the publisher

\section{INTRODUCTION}

Epidermal papillomatosis is mainly a virus-induced disease, described from several fish species (e.g. Bylund et al. 1980, Möller \& Anders 1986, Sano et al. 1991, Lee \& Whitfield 1992, Mellergaard \& Nielsen 1995, Premdas et al. 1995). However, the viral agents of papilloma have not been visualized or defined in all studies. Papillomata may erupt in fish due to various physiological stress factors, e.g. anoxia or environmental pollutants (Mellergaard \& Nielsen 1995, Premdas et al. 1995). Herpesvirus cyprini induced papilloma has been found to be virulent for carp fry (Sano et al. 1991). The clinical picture of papillomatosis, in general, includes white, smooth, loosely attached ovoid tumours on the skin and fins of fish. During severe infection, fish skin may be totally covered by hyperplasic epidermis. In smelt, large fish have been reported to have highest papilloma-tumour preva-

\footnotetext{
*Email: rkortet@st.jyu.fi
}

lences and intensities (Anders \& Möller 1985, Lee \& Whitfield 1992).

Roach is a common cyprinid fish spawning in spring in large groups. Individuals migrate to spawning sites (L'Abée-Lund \& Vøllestad 1985, Mills 1991, Kestemont et al. 1999), such as littoral waters, bays, creeks and small ponds, which warm early in the spring. Roach breeding is a lek-like mating system (Wedekind 1996), where males show secondary sexual characters, breeding tubercles, which are associated with sex hormones (Wiley \& Collette 1970). Sexual maturity and reproduction causes hormonal and physiological stress (see e.g. Pottinger \& Carrick 2000), which may induce papillomatosis during the spawning period. Prior to our study, several observations of epidermal skin diseases were made in roach in the present study areas, but detailed studies of papillomatosis on roach were lacking.

The aim of the work was to explore papillomatosis in roach: seasonal occurrence, gender and size dependence, and association to environmental factors. To our knowledge, sex dependence has not been previously reported on teleost papillomatosis. Due to the sug- 
gested immunomodulative role of androgens (Folstad \& Karter 1992, Braude et al. 1999) and intensive spawning of roach (Wedekind 1996), we expected males to have higher prevalences and intensities of papilloma, especially during spawning. We studied the prevalence of the disease during spawning from separated roach populations in randomly chosen polluted and non-polluted waters to monitor the possible environmental aspects of the phenomenon (Möller \& Anders 1986). In one of the populations, we also studied the seasonal pattern of the disease.

\section{MATERIALS AND METHODS}

A total of 1683 adult roach specimens (mean length \pm SD; $159.1 \pm 29 \mathrm{~mm}$ ) were collected using netting, and studied during the spawning period from 6 populations between April and May 1999, and from 11 populations in 2000. Sampled populations, exact sample sizes and dates are given in Table 1. The sampled populations were classified into 2 groups by their pollution backround (e.g. Paasivirta et al. 1986, Granberg 1987): (1) human-impact waters including industrial and/or sewage effluents, and (2) non-human-impact waters (see Table 1). The study populations were from separate areas, and were within $100 \mathrm{~km}$ distance from the city of
Jyväskylä (62 ${ }^{\circ} 14^{\prime} \mathrm{N}, 25^{\circ} 46^{\prime} \mathrm{E}$, central Finland), except for Lake Viitajärvi ( $64^{\circ} 38^{\prime}$ N, $24^{\circ} 26^{\prime}$ E, the Baltic Sea population, northern Finland) and River Alajoki (60 $90^{\prime} \mathrm{N}$, $28^{\circ} 12^{\prime} \mathrm{E}$, discharging to the Baltic Sea, south-east Finland).

The seasonal occurrence of the disease was studied from 8 additional samples $(n=434)$ taken between February and November 1999 from Lake Jyväsjärvi. This lake was chosen for the seasonal study, because earlier observations indicated that disease occurrence was most severe in this lake. Exact monthly sample sizes and dates for Lake Jyväsjärvi are given in Fig. 1. Fish were caught by angling and netting.

Fish were killed with a sharp blow to the head immediately after catching. We measured the fork length of the fish and determined the sex by examining the gonads. We categorised the fish into 4 groups by their papilloma neoplasms: (0) fish having no visible tumours; (1) fish carrying less than 5 small $(<5 \mathrm{~mm}$ diameter) tumours or 1 medium (5 to $10 \mathrm{~mm}$ diameter) tumour; (2) fish having at least 1 large (>10 $\mathrm{mm}$ in diameter) tumour or more than 5 small tumours; and (3) fish having at least 1 quarter of the skin covered by papilloma tumours. Papilloma disease was identified histologically from 10 tumours in the Veterinary Research Institute of Finland (EELA), Helsinki, by Dr. Eija Rimaila-Pärnänen.

Table 1. Rutilus rutilus. Sampled populations categorised into 2 categories of degree of human impact (HI) upon them: (1) $\mathrm{P}=$ paper and pulp industry, $\mathrm{B}=\mathrm{PCB}, \mathrm{L}=$ sulphite lye, $\mathrm{S}=$ sewage effluents, $\mathrm{H}=$ heavy metals; (2) $\mathrm{N}=$ no remarkable industrial or sewage effluents. Sampling dates and prevalences $(P)$ of roach papillomatosis. Heavily infected fish had at least 1 large $(>10 \mathrm{~mm}$ diameter) tumour or more than 5 small tumours

\begin{tabular}{|c|c|c|c|c|c|c|c|c|c|}
\hline \multirow[t]{2}{*}{ Population } & \multirow[t]{2}{*}{$\mathrm{HI}$} & \multirow{2}{*}{$\begin{array}{c}\text { Date } \\
\text { (d.mo.yr) }\end{array}$} & \multirow[t]{2}{*}{$\mathrm{n}$} & \multicolumn{3}{|c|}{$P(\%)$} & \multicolumn{3}{|c|}{$P(\%$, heavily infected $)$} \\
\hline & & & & Males & Females & Both & Males & Females & Both \\
\hline \multicolumn{10}{|l|}{ Category 1} \\
\hline Lake Jyväsjärvi & $\mathrm{P}, \mathrm{B}, \mathrm{S}$ & $\begin{array}{c}26.5 .99 \\
22-26.5 .00\end{array}$ & $\begin{array}{r}83 \\
134\end{array}$ & $\begin{array}{l}78.3 \\
71.4\end{array}$ & $\begin{array}{r}35.1 \\
7.5\end{array}$ & $\begin{array}{l}62.0 \\
20.9\end{array}$ & $\begin{array}{l}45.4 \\
28.5\end{array}$ & $\begin{array}{l}0.0 \\
1.9\end{array}$ & $\begin{array}{r}25.4 \\
7.5\end{array}$ \\
\hline Lake Päijänne & $\mathrm{P}, \mathrm{S}$ & $\begin{array}{c}25.5 .99 \\
19-20.5 .00\end{array}$ & $\begin{array}{l}131 \\
127\end{array}$ & $\begin{array}{l}35.1 \\
21.5\end{array}$ & $\begin{array}{l}10.0 \\
13.1\end{array}$ & $\begin{array}{l}17.6 \\
17.5\end{array}$ & $\begin{array}{l}7.7 \\
6.1\end{array}$ & $\begin{array}{l}0.0 \\
4.9\end{array}$ & $\begin{array}{l}2.3 \\
5.6\end{array}$ \\
\hline Lake Saravesi & $\mathrm{P}$ & $\begin{array}{l}12.6 .99 \\
13.5 .00\end{array}$ & $\begin{array}{r}39 \\
108\end{array}$ & $\begin{array}{l}20.0 \\
22.7\end{array}$ & $\begin{array}{l}0.0 \\
1.2\end{array}$ & $\begin{array}{r}15.4 \\
5.6\end{array}$ & $\begin{array}{l}3.3 \\
0.0\end{array}$ & $\begin{array}{l}0.0 \\
0.0\end{array}$ & $\begin{array}{l}2.6 \\
0.0\end{array}$ \\
\hline Lake Koivujärvi & $\mathrm{P}, \mathrm{L}, \mathrm{H}$ & 30.5 .00 & 63 & 10.0 & 5.7 & 6.3 & 0.0 & 0.0 & 0.0 \\
\hline Lake Vihtajärvi & $\mathrm{H}$ & 29.5 .00 & 116 & 3.6 & 0.0 & 0.9 & 0.0 & 0.0 & 0.0 \\
\hline Lake Tuomiojärvi & $\mathrm{S}$ & 18.5 .00 & 54 & 42.9 & 9.1 & 22.2 & 0.0 & 0.0 & 0.0 \\
\hline $\begin{array}{l}\text { Lake Viitajärvi (Baltic } \\
\text { Sea population) }\end{array}$ & $\mathrm{S}$ & 4.5 .00 & 102 & 49.0 & 5.9 & 27.5 & 7.8 & 0.0 & 3.9 \\
\hline \multicolumn{10}{|l|}{ Category 2} \\
\hline Lake Lahnajärvi & $\mathrm{N}$ & $\begin{array}{l}23.5 .99 \\
15.5 .00\end{array}$ & $\begin{array}{r}72 \\
152\end{array}$ & $\begin{array}{l}0.0 \\
0.0\end{array}$ & $\begin{array}{l}0.0 \\
0.0\end{array}$ & $\begin{array}{l}0.0 \\
0.0\end{array}$ & $\begin{array}{l}0.0 \\
0.0\end{array}$ & $\begin{array}{l}0.0 \\
0.0\end{array}$ & $\begin{array}{l}0.0 \\
0.0\end{array}$ \\
\hline Lake Konnevesi & $\mathrm{N}$ & $\begin{array}{l}19.5 .99 \\
19.5 .00\end{array}$ & $\begin{array}{r}112 \\
81\end{array}$ & $\begin{array}{r}10.3 \\
9.8\end{array}$ & $\begin{array}{l}0.0 \\
0.0\end{array}$ & $\begin{array}{l}2.7 \\
6.2\end{array}$ & $\begin{array}{l}0.0 \\
2.0\end{array}$ & $\begin{array}{l}0.0 \\
0.0\end{array}$ & $\begin{array}{l}0.0 \\
1.2\end{array}$ \\
\hline Lake Kuuhankavesi & $\mathrm{N}$ & $\begin{array}{c}24.5 .99 \\
6.5 .00\end{array}$ & $\begin{array}{l}101 \\
101\end{array}$ & $\begin{array}{l}0.0 \\
0.0\end{array}$ & $\begin{array}{l}0.0 \\
0.0\end{array}$ & $\begin{array}{l}0.0 \\
0.0\end{array}$ & $\begin{array}{l}0.0 \\
0.0\end{array}$ & $\begin{array}{l}0.0 \\
0.0\end{array}$ & $\begin{array}{l}0.0 \\
0.0\end{array}$ \\
\hline River Alajoki & $\mathrm{N}$ & 18.5 .00 & 107 & 0.0 & 0.0 & 0.0 & 0.0 & 0.0 & 0.0 \\
\hline
\end{tabular}


In statistical tests for papilloma prevalence all diseased fish were analysed in 1 group (Groups 1, 2 and 3 were pooled). We used logistic regression to analyse the relationships between papillomatosis prevalence, fish length and sex. The probability of fish to be diseased in relation to length was estimated for both sexes separately if sex was found to have an effect on the prevalence of papilloma. The differences between prevalence of the disease in human-impact populations $(\mathrm{n}=7)$ and non-human-impact populations $(\mathrm{n}=4)$ in 2000 were analysed using the Kruskal-Wallis test. The seasonal pattern of papillomatosis prevalence Lake Jyväsjärvi in 1999 was analysed using a $\chi^{2}$-test.

\section{RESULTS}

Samples collected during the spawning period revealed that the papilloma disease occurred in 8 of the 11 populations studied (Table 1). In most severe cases, tumours covered more than half of the skin of an individual fish. There was a clear variation in the prevalence of the disease among the study lakes (Table 1). The highest prevelence was found in Lake Jyväsjärvi (62\% in 1999 and $21 \%$ in 2000).

There were 2 seasonal peaks in papillomatosis in Lake Jyväsjärvi in 1999; the highest one during spawning and a lower one in August (Fig. 1). The prevalence of papillomatosis increased from $4 \%$ in early February to $62 \%$ in late May $\left(\chi^{2}=24.858, \mathrm{df}=1, \mathrm{p}<0.001\right)$. From late May, the prevalence decreased to $6 \%$ on July 19 $\left(\chi^{2}=23.087, \mathrm{df}=1, \mathrm{p}<0.001\right)$. From July 19 to August 18 the prevalence increased to $18 \%\left(\chi^{2}=127.69, \mathrm{df}=1\right.$, $\mathrm{p}<0.001$ ). From August onwards, the prevalence decreased to $5 \%$ by November, which was close to the value observed in February. The intensity of the disease had a similar seasonal pattern as the prevalence (Fig. 1). Severely diseased fish were mostly found around spawning period. Signs of healed tumours were observed on 16 individual fish in July, August and October. Those signs were thin greenish healed papilloma tumours and skin darkening. Recovered fish were regarded as undiseased individuals in statistical analyses.

The results of logistic regression indicated that both sex and length of fish affected the prevalence of disease, as the logistic regression model included both variables, in Lake Jyväsjärvi populations (for model: $\left(\chi^{2}=110.764, \mathrm{df}=2, \mathrm{p}<0.001\right.$ ), Lake Päijänne (for model: $\mathrm{c}^{2}=83.528, \mathrm{df}=2, \mathrm{p}<0.001$ ), Lake Saravesi (for model: $\left(\chi^{2}=23.424, \mathrm{df}=2, \mathrm{p}<0.001\right)$, Lake Tuomiojärvi (for model: $\mathrm{c}^{2}=12.902, \mathrm{df}=2, \mathrm{p}=0.002$ ) and Lake Viitajärvi (for model: $\left(\chi^{2}=47.811, \mathrm{df}=2, \mathrm{p}<0.001\right)$. Bigger fish and males were more frequently diseased than smaller fish and females. To visualise the sex and

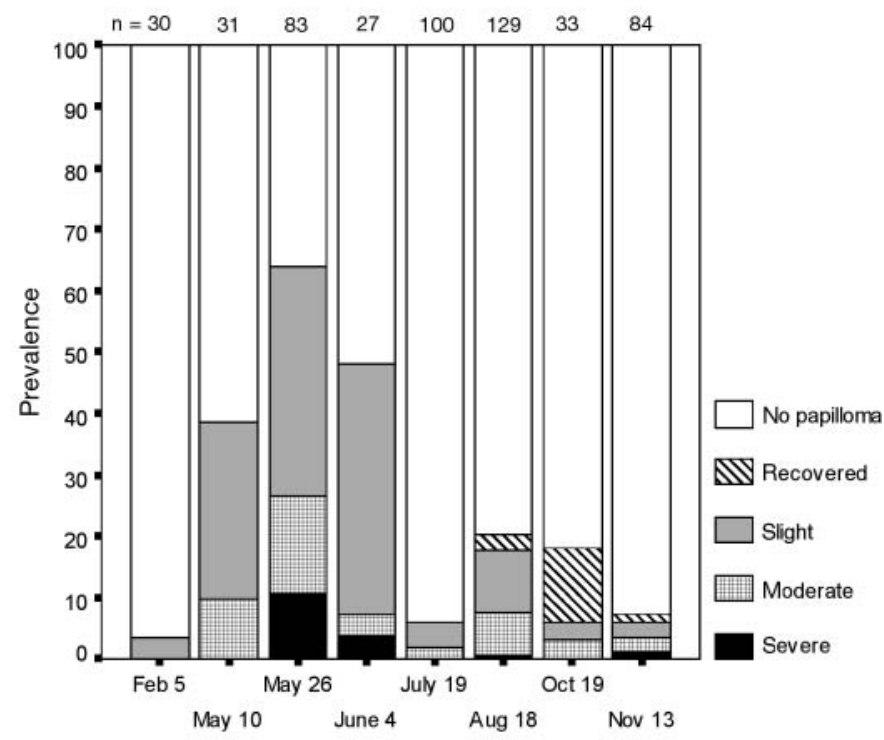

Fig. 1. Rutilus rutilus. Temporal changes in papilloma disease of male and female roach from Lake Jyväsjärvi between February and October 1999. Statistically significant changes in prevalence were found from February to May 26, May 26 to July and July to August (see 'Results')

size dependence, we fitted a logistic regression curve to data for Lake Jyväsjärvi and Lake Päijänne populations (Fig. 2). In Lake Koivujärvi, neither fish sex nor length affected the papilloma prevalence (for model: $\chi^{2}=3.421, \mathrm{df}=2, \mathrm{p}=0.181$ ). No diseased females were found in Lake Konnevesi or Lake Vihtajärvi. Male length was related positively to papilloma prevalence in Lake Konnevesi (for model: $\chi^{2}=20.452, \mathrm{df}=1, \mathrm{p}=$ 0.019 ), but not in Lake Vihtajärvi (for model: $\chi^{2}=$ $0.515, \mathrm{df}=1, \mathrm{p}=0.473$ ).

In the populations that were subjected to industrial or sewage effluents $(\mathrm{n}=7$; Table 1$)$ the mean prevalence of papillomatosis in 2000 was $14 \%$, which was significantly higher than among non-human-impact populations; $\mathrm{n}=4$, prevalence $2 \%$ (Kruskal-Wallis test; $\left.\chi^{2}=5.238, \mathrm{df}=4, \mathrm{p}=0.022\right)$.

\section{DISCUSSION}

We found that epidermal papillomatosis occurred in the majority of the lakes we studied during spawning periods in 1999 and 2000. Seasonal study in one lake showed that the disease occurrence peaked during the spawning period. We also found a clear gender dependence in the presence of papillomatosis, and the pattern was similar in most of the populations where the tumours were present. Length was also related positively to papilloma in 6 of the 8 populations. Popula- 


\section{Lake Jyväsjärvi}

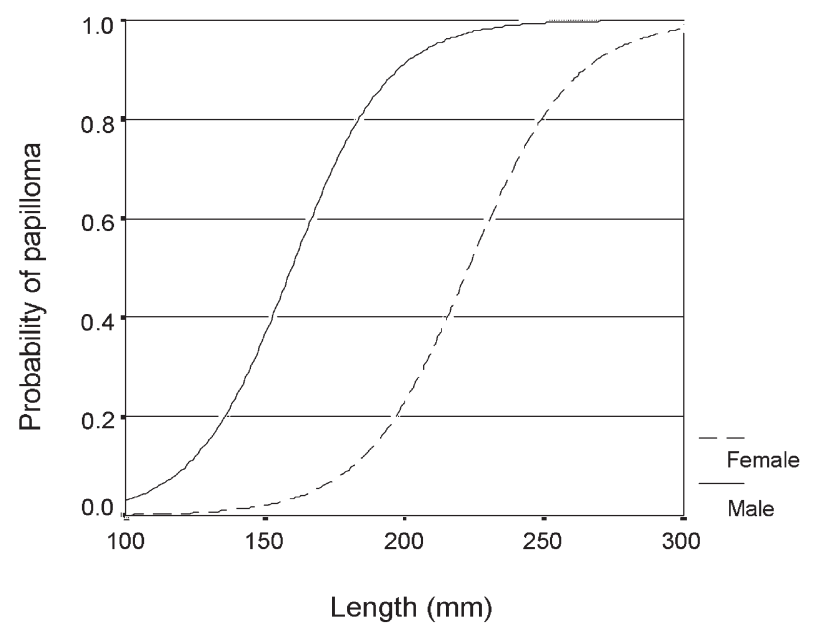

\section{Lake Päijänne}

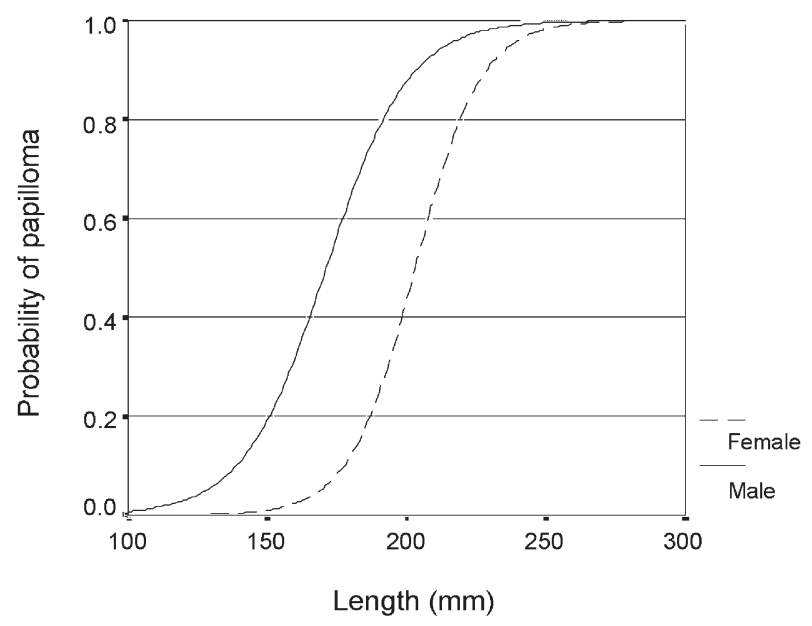

Fig. 2. Rutilus rutilus. The risk of papillomatosis in relation to the length of male and female roach from Lake Jyväsjärvi (actual data range: males, 143 to $239 \mathrm{~mm}$; females, 143 to $255 \mathrm{~mm}$ ) and Lake Päijänne (actual data range: males, 110 to $282 \mathrm{~mm}$; females, 111 to $216 \mathrm{~mm}$ ). The equation for papilloma probability:

$$
P=\frac{1}{1+\mathrm{e}^{-\left(B_{0}+B_{1} \times L\right)}}
$$

where $B_{0}$ and $B_{1}$ are the odds ratio of being non-diseased and diseased, respectively, and $L$ is length. The equation was estimated using logistic regression (Lake Jyväsjärvi: males $B_{0}=$ -9.252, $B_{1}=0.058$, Nagelkerke $R^{2}=0.212, p=0.004$, and females $B_{0}=-11.866, B_{1}=0.053$, Nagelkerke $\mathrm{R}^{2}=0.192, \mathrm{p}<$ 0.001; Lake Päijänne: males $B_{0}=-11.641, B_{1}=0.068$, Nagelkerke $\mathrm{R}^{2}=0.446, \mathrm{p}<0.001$, and females $B_{0}=-17.465, B_{1}=$ 0.086 , Nagelkerke $\mathrm{R}^{2}=0.417, \mathrm{p}<0.001$ )

tions subject to industrial or sewage effluents had a higher prevalence of papillomatosis than non-humanimpact populations.
Observed seasonality in roach papillomatosis is clearly connected to breeding period, such that the expression 'spawning papillomatosis' can be used. Epizootic papillomatosis during the spawning period has also been described in smelt (Anders \& Möller 1985, Lee \& Whitfield 1992). Several indications of a dysfunction in fish immune defence during the reproductive period are known (Iida et al. 1989, Slater \& Schreck 1998, Hou et al. 1999, Skarstein et al. 2001). A decrease in the fish immunocompetence may increase the risk of infections and diseases during sexual maturation and reproduction. For example, in roach, a peak in Gyrodactylus monogenean parasites during the breeding season has been described (Koskivaara et al. 1991). In addition, an increase in ultraviolet irradiation in spring may interfere with the fish immune system in the spring, since exposure to ultraviolet B irradiation has been found to lower the immune defence in roach (Salo et al. 1998, 2000), and this species spawns in shallow waters (e.g. Mills 1991). Many fish species show seasonal reduction or complete loss of club cells during the breeding season, and the loss is higher in males than in females (Irving 1996). Club cells may play a role in nonspecific mucosal defence mechanisms in fish. Therefore, the reason for the papilloma outbreak during spawning may be lowered immune status of fish at that time due to physical stresses and hormonal changes. Moreover, while spawning-related changes in hormone levels may alter immune function, hormones might also act directly on tumor cells, stimulating replication. Alternatively, fish may be exposed more to disease agents during their intensive breeding period. A latent carrier of papilloma agents may be present in fish stocks around the year but the spawning stress and changing sex hormone levels may stimulate its manifestation, as has also been suggested by Lee \& Whitfield (1992). At least some fish may recover from the disease, since we found a few roach specimens with healed tumours, but the latent infection may remain. The observed second seasonal peak which was lower in papillomatosis in Lake Jyväsjärvi may be due to stress caused by algal blooms in August. Unfortunately, no water-quality data are available for that period. The role of rising water temperature to papilloma outbreak is not likely, since Sano et al. (1993) found a regression of papillomatosis induced by Herpesvirus cyprini in rising water temperature in fancy carp Cyprinus carpio.

Roach males produce breeding tubercles during spawning. Breeding tubercles are keratinised epidermal nodules, which are found commonly in many fish taxa, more often in males (see review in Wiley \& Collette 1970). In general, organs are particularly vulnarable to tumorigenesis during the rapid growth and differentation (Walter \& Israel 1987). Clear morpholog- 
ical changes in the skin, like breeding tubercles, may per se increase the risk of epidermal diseases in males, because growing or transient body tissue cells may be more vulnerable to pathogenic infections, replication and tumorigenesis. This could contribute to the observed higher prevalence of papillomatosis in male fish. On the other hand, sex hormones are commonly associated with decreased immunocompetence (Iida et al. 1989, Slater \& Schreck 1998, Hou et al. 1999), and androgens may have an effect on papilloma disease outbreaks. In salmon, Bylund et al. (1980) suggested an association of papillomatosis with physiological, primarily hormonal, changes. The gender dependence in disease prevalence may also indicate that the possible trade-off between reproduction and immune defence may be more clear in males than in females. Roach spawning is an intensive lek-like mating (Wedekind 1996), which may be more stressfull for males than females and thus induce more papillomatosis among males. The potential role of epidermal injury in aggressive or sexual encourters of males may be important in papilloma tumorigenesis, since replicating cells in the epidermis might be the main substrate for neoplasms (Walter \& Israel 1987). In general, the finding of higher incidences of tumors in males would be enhanced if greater rates of viral infection and/or viral replication could be demonstrated in males, thus clarifying the pathogenesis of the papillomatosis.

In addition to gender dependence, we found that length affects the occurrence of papilloma disease. Similar size dependence has also been found in earlier studies with smelt (Anders \& Möller 1985, Lee \& Whitfield 1992). This phenomenon might also be explained by hormone-related changes in immune defence, if larger fish have higher levels of immunomodulative androgens (e.g. Cheek et al. 2000). Alternatively, the larger, i.e. older fish, may have a higher probability of exposure to a chronic papilloma agent. The largest fish are most likely to have been spawned in previous years.

Papilloma prevalences were higher in humanimpact-populations than in the populations with no industrial or sewage effluents. The industrial pollutants have been found to reduce immunoglobulin synthesis and chemotaxic migration of granulocytes in roach (Jokinen et al. 1995, Aaltonen et al. 2000). Since we did not investigate the detailed water quality of the sampled lakes, we cannot make far-reaching assumptions of the environmental impact to the disease prevalence. It is also possible that papilloma agent levels may be higher in human-impacted environments than non-human-impacted environments, possibly due to higher levels of diseased fish or higher densities of roach. However, the present results are similar to previous studies, indicating higher papillomatosis prevalences in polluted waters (e.g. Möller \& Anders 1986,
Premdas et al. 1995). Thus, the disease could possibly be used as a potential water-quality indicator, since roach is a common freshwater cyprinid living in various kinds of waterways. However, detailed experimental studies are needed to investigate the issue.

Spawning papilloma may have an impact on roach populations since the fish with severe infection may have an increased risk of secondary fungal or bacterial infections, or predation. The papilloma may also increase fish mortality (Sano et al. 1991). Interestingly, this roach disease might provide a good tool to model the immunocompetence handicap hypothesis of sexual selection (Folstad \& Karter 1992) in roach, if the costs of papilloma tumours differ among variously ornamented males. The main prediction of that hypothesis is that sexual ornaments, i.e. breeding tubercles in the case of roach, are produced by immunomodulative sex hormones. Unfortunately, the breeding tubercles of males were not studied in the present work.

To conclude, in line with previous studies, the results indicate that stressfull conditions, such as environmental stress, hormonal changes and physical stress during spawning, may expose fish to an outbreak of the papilloma disease. Roach males had a higher prevalence of papillomatosis than females, which may indicate more stressful conditions among male individuals, or a difference in immunocompetence between sexes. Alternatively, roach males may have higher exposure to papilloma agents during intensive spawning. Furthermore, since human-impact populations showed higher papillomatosis prevalences, the disease could possibly be used as a water-quality indicator.

Acknowledgements. We are grateful to V. Kupari, J. Kupari, and T. Sinisalo for assistance in the field and laboratory, and we thank E. T. Valtonen, K. Pulkkinen, A. Karvonen, M. J. Rantala, the Parasite Group of Jyväskylä University and 2 anonymous reviewers for helpful comments on the manuscript. We would also like to thank Jyväskylä Regional Environmental Centre for financial support for this study. We also thank Emil Aaltonen Foundation for a grant to R.K.

\section{LITERATURE CITED}

Aaltonen TM, Jokinen EI, Salo HM, Markkula SE, Lammi R (2000) Modulation of immune parameters of roach, Rutilus rutilus, exposed to untreated ECF and TCF bleached pulp effluents. Aquat Toxicol 47:277-289

Anders K, Möller H (1985) Spawning papillomatosis of smelt, Osmerus eperlanus L., from the Elbe estuary. J Fish Dis 8: 233-235

Braude S, Tang-Martinez Z, Taylor GT (1999) Stress, testosterone, and the immunoredistribution hypothesis. Behav Ecol 10:345-350

Bylund G, Valtonen ET, Niemelä E (1980) Observations on epidermal papillomata in wild and cultured Atlantic salmon Salmo salar L. in Finland. J Fish Dis 3:525-528

Cheek AO, Thomas P, Sullivan GV (2000) Sex steroids rela- 
tive to alternative mating behaviors in the simultaneous hermaphrodite Serranus subligarious (Perciformes: Serranidae). Horm Behav 37:189:211

Folstad I, Karter AJ (1992) Parasites, bright males, and the immunocompetence handicap. Am Nat 139:603-622

Granberg K (1987) Äänekoski-Vaajakoski vesireitin velvoitetarkkailu vuonna 1986: Jätevesikuormitus, fysikaalis-kemialliset tutkimukset, perustuotanto ja kasviplankton. Hydrobiologian tutkimuskeskuksen tiedonantoja. Yliopisto, Jyväskylän, p 1-23

Hou Y, Suzuki Y, Aida K (1999) Changes in immunoglobulin producing cells in response to gonadal maturation in rainbow trout. Fish Sci 65:844-849

Iida T, Takanishi K, Wakabayashi H (1989) Decrease in the bacterial activity of normal serum during the spawning period of rainbow trout. Bull Jpn Soc Sci Fish 55:463-465

Irving PW (1996) Sexual dimorphism in club cell distribution in the European minnow and immunocompetence signalling. J Fish Biol 48:80-88

Jokinen EI, Aaltonen TM, Valtonen ET (1995) Subchronic effects of pulp and paper mill effluents on the immunoglobulin synthesis of roach, Rutilus rutilus. Ecotoxicol Environ Saf 32:219-225

Kestemont P, Rinchard J, Feys V, Fostier A (1999) Spawning migrations, sexual maturity and sex steroid levels in female roach Rutilus rutilus from the River Meuse. Aquat Sci 61:111-121

Koskivaara M, Valtonen ET, Prost M (1991) Seasonal occurrence of gyrodactylid monogeneans on the roach (Rutilus rutilus) and variations between four lakes of differing water quality in Finland. Aqua Fenn 21:47-55

L'Abée-Lund JH, Vøllestad LA (1985) Homing precision of roach Rutilus rutilus in Lake Årungen, Norway. Environ Biol Fishes 13:235-239

Lee S, Whitfield PJ (1992) Virus-associated spawning papillomatosis in smelt, Osmerus eperlanus L., in the River Thames. J Fish Biol 40:503-510

Mellergaard S, Nielsen E (1995) Impact of oxygen deficiency on the disease status of common dab Limanda limanda. Dis Aquat Org 22:101-114

Mills CA (1991) Reproduction and life history. In: Winfield IJ, Nelson S (eds) Cyprinid fishes: systematics, biology and

Editorial responsibility: Jo-Ann Leong,

Corvallis, Oregon, USA exploitation. Chapman \& Hall, London, p 483-508

Möller H, Anders K (1986) Diseases and parasites of marine fishes, tumors and tumor-like lesions. Verlag Möller, Kiel, p 39-59

Paasivirta J, Mäntykoski K, Paukku R, Piilola T, Vihonen $H_{\text {, }}$ Särkkä J, Granberg K (1986) PCB in the sediments of the Lake Jyväsjärvi. Aqua Fenn 16:17-23

Pottinger TG, Carrick TR (2000) Contrasting seasonal modulation of the stress response in male and female rainbow trout. J Fish Biol 56:667-675

Premdas PD, Metcalfe TL, Bailey ME, Metcalfe CD (1995) The prevalence and histological appearance of lip papillomas in white suckers (I) from two sites in central Ontario, Canada. J Gt Lakes Res 21:207-219

Salo HM, Aaltonen TA, Markkula E, Jokinen EI (1998) Ultraviolet $\mathrm{B}$ irridation modulates the immune system of fish (Rutilus rutilus, Cyprinidae). I. Phagocytes. Photochem Photobiol 67(4):433-437

Salo HM, Jokinen EI, Markkula SE, Aaltonen TM, Penttilä HT (2000) Comparative effects of UVA and UVB irridation on the immune system of fish. J Photochem Photobiol B Biol $56: 154-162$

Sano N, Moriwake M, Sano T (1993) Herpesvirus cyprini: Thermal effects on pathogenicity and oncogenicity. Gyobyo Kenkyu 28(4):171-175

Sano T, Morita N, Shima N, Akimoto M (1991) Herpesvirus cyprini: lethality and oncogenity. J Fish Dis 14:533-543

Skarstein F, Folstad I, Liljedal S (2001) Whether to reproduce or not: immune suppression and cost of parasites during reproduction in the Arctic charr. Can J Zool 79:271-278

Slater CH, Schreck CB (1998) Season and physiological paremeters modulate salmonid leucocyte androgen receptor affinity and abundance. Fish Shellfish Immunol 8: 379-391

Walter JB, Israel MS (1987) General pathology. Churchill Livingstone, New York

Wedekind C (1996) Lek-like spawning behaviour and different female mate preferences in roach (Rutilus rutilus). Behaviour 133:681-695

Wiley ML, Collette BB (1970) Breeding tubercles and contact organs in fishes: their occurrence, structure, and significance. Bull Am Mus Nat Hist 143:145-216

Submitted: December 19, 2001; Accepted: June 17, 2002 Proofs received from author(s): November 13, 2002 